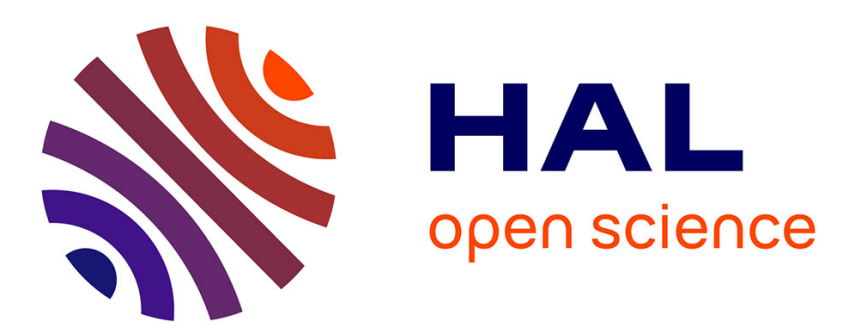

\title{
Domesticating and democratizing science: a geography of do-it-yourself biology
}

Morgan Meyer

\section{To cite this version:}

Morgan Meyer. Domesticating and democratizing science: a geography of do-it-yourself biology. 2013. hal-00784685

\section{HAL Id: hal-00784685}

https://hal-mines-paristech.archives-ouvertes.fr/hal-00784685

Preprint submitted on 4 Feb 2013

HAL is a multi-disciplinary open access archive for the deposit and dissemination of scientific research documents, whether they are published or not. The documents may come from teaching and research institutions in France or abroad, or from public or private research centers.
L'archive ouverte pluridisciplinaire HAL, est destinée au dépôt et à la diffusion de documents scientifiques de niveau recherche, publiés ou non, émanant des établissements d'enseignement et de recherche français ou étrangers, des laboratoires publics ou privés. 
$\mathbf{N}^{\circ} 032$

2013

Domesticating and democratizing science:

a geography of do-it-yourself biology

Morgan Meyer

Centre de sociologie de l'innovation, Mines-ParisTech morgan.meyer(a)mines-paristech.fr

Centre de Sociologie de l'INNOVATION

MINES PARISTECH / CNRS UMR 7185

60 Boulevard Saint-Michel

75272 Paris cedex 06 FRANCE

http://www.csi.mines-paristech.fr/ 
Cette collection a pour but de rendre aisément disponible un ensemble de documents de travail et autres matériaux de discussion issus des recherches menées au CSI (CENTRE DE SOCIOLOGIE DE L'INNOVATION).

Tous les droits afférant aux textes diffusés dans cette collection appartiennent aux auteurs.

Des versions ultérieures des papiers diffusés dans cette collection sont susceptibles de faire l'objet d'une publication. Veuillez consulter la base bibliographique des travaux du CSI pour obtenir la référence exacte d'une éventuelle version publiée.

CSI WORKING PAPERS SERIES

The aim of this collection is to make easily available a set of working papers and other materials for discussion produced at the CSI (CENTRE DE SOCIOLOGIE DE L'INNOVATION).

The copyright of the work made available within this series remains with the authors.

Further versions of these working papers may have been submitted for publication. Please check the bibliographic database of the CSI to obtain exact references of possible published versions. 


\title{
Domesticating and democratizing science: a geography of do-it-yourself biology
}

\section{Morgan Meyer}

Centre for the Sociology of Innovation, Mines ParisTech

\begin{abstract}
By turning private homes and community spaces into sites where biological experimentation can be carried out, do-it-yourself biology promises a democratization of science. This democratization is based upon material processes: efforts to increase the affordability, the accessibility and the mutability of scientific equipment can be observed. In particular, do-it-yourself biology relies on 'creative workarounds' around objects (to transform and combine them in novel ways) and around institutions (to circumvent established university-industry business linkages). By tinkering with objects and by sharing knowledge via various communicative devices - websites, blogs, wikis, forums, videos - do-ityourself biologists aim to create a new, collective and open economy of scientific equipment and render biology more accessible to citizens. A distinct form of individuality is constituted by providing people access, transforming them into active makers of science, making their bodies/aliments more knowable and demonstrating that one can do it oneself. Do-it-yourself biology thus offers a site for exploring the ethics, the boundaries and new forms of sociability for biology.
\end{abstract}

Key words: do-it-yourself biology, scientific equipment, boundaries, creative workarounds, geography of science

\section{Introduction}

Not far from Copenhagen's city centre, in the basement of an ordinary-looking building, there is an independent and curious space named Labitat. Crowded with all kinds of equipment - from computers and cables to electrode welders, incubators and 3D printers - the space is open to people interested in technology, art, design and science (see picture 1). Labitat is a so-called 'makerspace' or 'hackerspace', a place where people do stuff, where they create and tinker in a rather friendly, open, creative and collective atmosphere. In one of the rooms of this hackerspace, there is even a lab bench and scientific equipment to do biological experiments. We can see a centrifuge, hot plates, pipettes and scales. 'Garage biology' is what happens here, 
and the group of people involved calls itself BiologiGaragen. Over the past two years various workshops and activities have been organized at BiologiGaragen: to learn how to 'hack' yoghurt, how to extract and visualize DNA, how to build one's own centrifuges, microscopes, fermenters and stirring plates. BiologiGaragen is an interesting place where experimentation with science, technology but also new forms of sociability seem to occur concurrently.

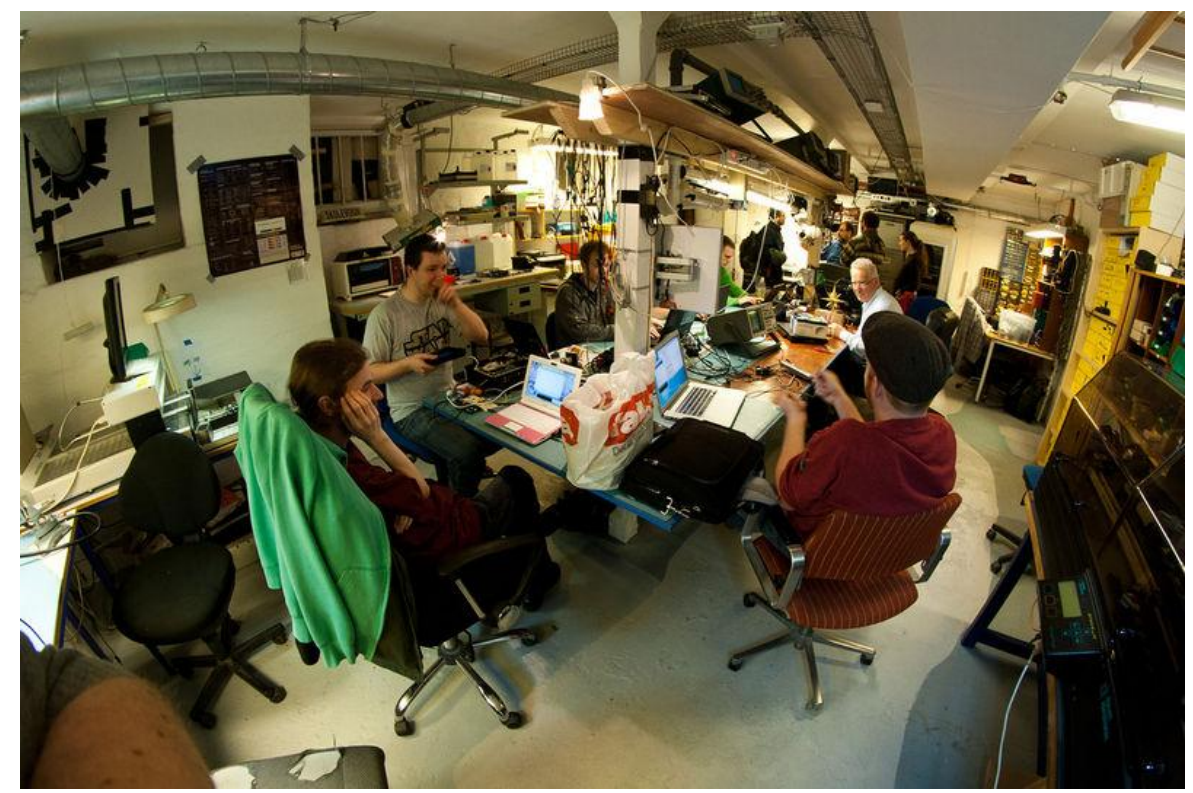

Picture 1: Labitat, Copenhagen (source: Labitat).

Be it in Copenhagen, New York, Paris, or Singapore, there is today an increasing number of enthusiasts who, in rudimentary laboratories built in garages, kitchens, or basements, experiment with molecular or synthetic biology. At the time of writing there are more than 30 community laboratories dedicated to this kind of garage biology across the world. This 'garage biology' or 'do-it-yourself biology' raises a number of issues and has caught the attention of several commentators and science journalists (i.e. Ledford 2010, Sawyer 2011, Wohlsen 2011, Wolinsky 2009). Do-ityourself biology is often praised for the potential it holds for democratizing science, for fostering a 'citizen science', for the empowerment of ordinary people and for its educational, economic and socio-cultural value. For instance, it is argued that do-ityourself biology is more than just a hobby for 'it democratizes science and gives people access to their own biological data in the most direct way possible' (Wolinsky 2009: 684). Its practitioners are said to be a 'creative proof of the hacker principle' (Ledford 2010: 650) and it therefore represents an 'example of a direct translation of free software and hacking practices into the realm of cells, genes, and labs' (Delfanti 2010: 108). Delfanti (2010: 119) writes: 'DIYbio embodies very different faces of hacking such as openness in data and knowledge sharing as well as openness of the doors of scientific institutions, but also rebellion, hedonism, passion, communitarian spirit, individualism and entrepreneurial drive, distrust for bureaucracies'. But concerns about these new forms and places of biology are also raised: tinkering with 
biology outside scientific institutions is a potential threat for national security, for people's safety and for the environment.

The starting point of this paper is an obvious, but crucial feature of do-it-yourself biology: it's an endeavour that takes place within the confines of people's private homes or within community spaces. By bringing biology into garages and basements the boundaries between amateurs and experts, scientists and citizens, universities and homes are potentially reconfigured. Other boundaries become particularly salient and problematic throughout these shifts: between responsible and criminal usages of technology, between the safe handling of the biological and hazardous experiments, between the laboratory and the exterior world, between do-it-yourself biology and 'true' university-based biology, between open biology and corporate biology. The rise of do-it-yourself biology calls therefore for an analysis of its spatiality and materiality: where precisely does do-it-yourself biology take place? Where and how do people share their knowledge in order to build their labs? In short, the geography of do-ityourself biology deserves academic scrutiny. This paper pursues two aims: to analyse the spatiality and materiality of do-it-yourself biology and to examine the various kinds of boundary-work manifest in recent discussions and debates. The paper thus aims to contribute to the growing literature on the geography of science (see i.e. Livingstone 2003, Naylor 2005, Powell 2007, Finnegan 2008) by focusing on emerging and less institutionalized sites of science.

Robert Carlson, now a prominent figure in the field, predicted in 2001 that 'Biological engineering will proceed from profession, to vocation, to avocation, because the availability of inexpensive, quality DNA sequencing and synthesis equipment will allow participation by anyone who wants to learn the details'. An analysis of these shifts thus also entails an examination of the techniques and material objects that are used to turn private homes and community spaces into sites of scientific experimentation. I thus follow the approach of Shove et al. (2007: 41-68) and focus on the tools and materials, rather than the symbolic meanings and effects of, do-ityourself practices.

In the next part, I provide a review of the spaces of amateur science, that is, the places and disciplines in which we find amateurs producing scientific knowledge. Thereafter, I present a brief overview of the rise of do-it-yourself biology. I then explore in more detail two laboratories in which do-it-yourself biologists work: one community laboratory (BiologiGaragen in Copenhagen) and one private laboratory. Of special concern will be the materials, tools, and objects that are shared, (re)build, or bought in order to build laboratories - such as the various alternatives for the PCR machine. In the last part of the paper, I will look at the various kinds of boundary-work present in the discussions about do-it-yourself biology. 


\section{Spaces and boundaries of amateur science}

Collaborations between professionals and amateurs, and the fact that enthusiasts and volunteers produce science is not a recent phenomenon. Quite the contrary: scientific work has since its beginnings been carried out by diverse groups of actors: researchers, amateurs, professionals, patients, etc. Four examples can be mentioned here.

A first example is what has been called popular epidemiology, 'a process by which laypersons gather scientific data and other information and direct and marshal the knowledge and resources of experts to understand the epidemiology of disease' (Brown 1992). Second, AIDS treatment activists are also involved in the production and evaluation of biomedical knowledge (Epstein 1995). In this case too, laypeople are engaged in scientific practice and thus challenging the idea that only experts can engage in research practices. A third example is the French Association of Muscular Dystrophy (Callon 1998, Callon et al. 2001), an association mainly composed of patients and their families that is sometimes actively involved in scientific research and collaborates with professionals. And, forth, in natural history there is a long tradition of amateurs doing fieldwork and producing knowledge (Alberti 2001, Charvolin et al. 2007, Heaton et al. 2011). In all these cases, the production of knowledge is a collective work where users are particularly active, rather than an activity confined only to researchers. In this 'model of co-production' of knowledge (Callon 1998), a form of organization permits a close cooperation between specialized people and laypersons.

These are just a few sites of what we could call the spaces of amateur science. The spaces of amateur science are, on the one hand, related to specific disciplinary fields: natural history (including botany, zoology, entomology, ornithology), astronomy, epidemiology, etc. On the other hand, there are specific physical locations in which we can observe amateurs producing and sharing knowledge: the field (to do observations (see Kuklick and Kohler 1996)), the museum (to work with specimens (Ellis and Waterton 2005, Star and Griesemer, 1989), the pub or the coffee house (as a meeting place for learned societies (see Secord 1996)), or even the home (Meyer 2008).

Livingstone (2003: 42) writes that the field, for instance, is 'an open space [...] less easily defined, bounded, and policed than its intramural counterparts like the laboratory or the museum'. In a similar vein, it has been argued that 'cultural translation remains a persistent and pervasive possibility in the field sciences, far more than in the laboratory disciplines' and that relationships between professionals and amateurs in field sciences 'have almost no parallel in the laboratory sciences' (Kuklick and Kohler 1996: 4, see also Kraft and Alberti 2003). Perhaps, with the rise of synthetic biology and do-it-yourself biology, the laboratory can now also potentially become a place of 'cultural translation' between amateurs and professionals. This 
paper will explore how such a 'cultural translation' is possible via a material transformation: garages and basements being transformed into laboratories, mundane objects into scientific equipment.

The spaces of amateur science and those of professional science do sometimes overlap and the examination of the relationships between amateurs and professionals therefore 'requires geographical sensitivity' (Alberti 2001: 142). Yet, despite - and most probably because of - these relationships it is not uncommon to see the boundaries of 'professional' science being articulated and policed. Boundarywork around definitions and territories of knowledge production is a common feature. But what exactly demarcates science is not some set of essential or transcendent characteristics or methods but, or so it is argued, an array of contingent circumstances (Guston 2001: 399, Evans 2005: 3). The demarcation of science is a matter of power and authority, rather than a matter of truth (Evans 2005: 7). Gieryn $(1983,1999)$ sees science as a space on maps of culture, bounded off from other territories. He writes: 'These cultural maps locate (that is, give a meaning to) white lab coats, laboratories, technical journals, norms of scientific practice, linear accelerators, statistical data, and expertise' (Gieryn 1999: x). The spaces in and around the edges are a perpetually contested terrain and what is at stake is the credibility and authority of science within 'credibility contests'. These contests divide into three genres, into different sorts of 'boundary-work': expulsion, expansion, and protection of autonomy. Throughout expulsion 'Real science is demarcated from several categories of posers: pseudo science, amateur science, [...] Boundary-work becomes a means of social control' (Gieryn 1999: 16). Expansion is when 'rival epistemic authorities square off for [...] control over a contested ontological domain' (Gieryn 1999: 16). And during protection of autonomy: 'scientists put up interpretative walls to protect their professional authority' especially if outside powers try 'to exploit that authority in ways that compromise the material and symbolic resources of science inside' (Gieryn 1999: 17).

Boundary crossings between amateurs and professionals have a long tradition. In natural history and astronomy, for example, there has always been a rich exchange between amateurs and professionals. Even with the development of laboratory biology at the end of the nineteenth century, amateurs continued to collaborate with laboratory biologists (Alberti 2001). In the field of medicine, there are patient associations who have been involved in scientific research since several decades (Rabeharisoa et al. 1998, Rabeharisoa and Callon 1999). Do-it-yourself biology thus represents both a continuation and a rupture in the history of amateurs' place in science. There is continuity, since the co-production of knowledge between amateurs and professionals has always existed and because tinkering with objects and equipment is a common activity among amateurs (and also among professionals). But, nevertheless, the 'amateurization' of molecular biology and the possibility of building biology laboratories outside institutions is also something novel and the creation of new tools, networks, associations, names and controversies reveal a 
certain originality of the movement. One difference between fields such as natural history and do-it-yourself biology is that they represent different 'ways of knowing' the former concerned with observing and describing the natural world, the latter with accessing, experimenting and engineering the biological world (Pickstone (2000) talks about three 'ways of knowing': natural history, the description and classification of things; the analysis of things into various kinds of elements; and experimenting to control phenomena and to systematically create novelties.) In some ways, do-ityourself biology might even be seen as a new phenomenon because it promises a 'return' to the 'roots of biology' (according to the co-founder of DIYbio (cited in Anonymous 2009b)). While in the seventeenth and eighteenth centuries places of residence and places where scientific knowledge was made were closely related, the 'disjunction' between these two places is nowadays 'almost absolute' (Shapin 1988: 404). Do-it-yourself biology thus reproblematizes some boundaries that have become taken for granted.

\section{The spaces of do-it-yourself biology}

The origins of do-it-yourself biology are multiple. In fact, a thorough description of doit-yourself biology would need to focus on its close entanglements with hackerspaces, with synthetic biology, with the open source movement, with do-ityourself, etc. (which is beyond the scope of this paper, but see i.e. Delfanti 2010, Kelty 2010, Roosth 2010, Bennett et al. 2009). Let us briefly mention the links between do-it-yourself biology and the open source and hacker movements. Do-ityourself biology is part of the broader open science movement, a movement itself inspired by the open source movement which has developed since the 1990s (see Ledford 2010). For some years now, the open source movement is developing in the world of biotechnology and the question often asked is whether the effects will be comparable to those in the computer field (where open source software are now common) (Hope 2008). Also, there is a close link between the hacker movement and do-it-yourself biology: the tools and physical spaces of hackerspaces and do-ityourself laboratories are often shared; on a semantic level we have seen hybrid terms such as 'biohacker' or 'biopunk' emerge; and the ethics and practices of hackers (i.e. favouring access, sharing, collaboration, decentralization) are similar to the ones discernable in do-it-yourself biology.

While Carlson argued in 2005 that 'The advent of garage biology is at hand' (Carlson 2005) and while terms such as 'garage biology' and 'do-it-yourself biology' subsequently began to appear in articles, it wasn't until 2008 and 2009, that these terms were circulated more widely. The first formal association dedicated to do-ityourself biology, DIYbio (Do-it-yourself Biology), was created in the Boston area in 2008. The first meeting of the group took place in an Irish pub in Cambridge with around 25 people present (including engineers, students, and professors) (see 
Roosth 2010). There has been a steady rise of members and DIYbio now counts more than 2000 members. Over the past few years, associations dedicated to do-ityourself biology have been established 'all over the globe' (DIYbio website): in India (Bangalore), Denmark (Copenhagen), the Czech Republic (Prague), Belgium (Namur), the UK (London, Manchester, Newcastle), the Netherlands (Amsterdam), Spain (Madrid), France (Paris), Austria (Vienna), Canada (Toronto, Vancouver, Victoria), Singapore, Israel (Tel Aviv), Germany, Ireland (Cork), Australia (Sydney). Most do-it-yourself biology groups, however, are located in the US (Atlanta, Baltimore, Boston, Brooklyn, Cambridge, Chicago, Houston, Los Angeles, New York, San Diego, San Francisco, Seattle, Sunnyvale). In Asia, do-it-yourself laboratories and hackerspaces have recently been set up in Singapore, Japan and Indonesia (Kera 2012). And at the time of writing, the creation of a European association of doit-yourself biology is under way: a first 'kick-off' meeting took place in Paris in December 2012 and further meetings are scheduled. The reasons to create a European community of do-it-yourself biology are that, first, European practitioners feel that there is a difference between the US and their approach to the field and, second, because they want to create a structure for facilitating collaborations, networking and funding amongst regional do-it-yourself groups.

So while there are now many groups that have emerged over the past 4 or 5 years and while many of them now possess dedicated websites, blogs, or even physical laboratory spaces, it proves difficult to estimate the number of individuals who actually do biology at home or in community labs. Assessments vary greatly. For instance, a science studies scholar stated in 2010 that 'no active garage laboratories exist [...] media attention overstates and mythologizes very poor practices: right now garage biology is not a site of research and innovation' (Delfanti 2010: 109-10). This contrasts with journalists reporting about 'hundreds of these homegrown scientists, and many do highly specialized research on DNA sequencing and experiments with live bacteria' (Anonymous 2009b) or that 'Amateur scientists are creating mutant microbes in labs they've set up in their own homes' (Moore 2009). It is, on the one hand, difficult to estimate the scope of do-it-yourself biology at this point in time for at least two reasons: it is a recent and emerging phenomenon and it takes place at home and in community laboratories and is thus less public, institutionalized, and visible than biology done at university laboratories for example. On the other hand, do-it-yourself biology has now become a visible phenomenon. There are today more than 30 community laboratories across the world, most of which stress that they are 'transparent' and aim to provide 'open access', and some of which have had quite extensive media coverage.

People who engage in do-it-yourself biology usually come from various backgrounds and have various interests and motivations: tinkering, having fun, creating, experimenting. We find biologists, computer scientists, bioartists, students, university professors, etc. (Delfanti 2010). As in the field sciences, practitioners are heterogeneous, communities are open, and members join networks with varying 
degrees of intensity (Kuklick and Kohler 1996: 6). (Given this diversity of motivations, interests and forms of association and given the multiplicity of identities and places that characterize the field, do-it-yourself biology does not resemble a unified and stabilized community but rather an 'epistemic collective', that is, a rather loose, emerging, heterogeneous and distributed collective of objects, places and people that is only partially stabilized (Meyer 2010).) The projects do-it-yourself biologists work on also vary greatly: extracting their own DNA, doing tests to detect genetic diseases, trying to build alternatives to expensive equipment, doing outreach activities, or doing more funny experiments like producing fluorescent yoghurt or brewing alcohol.

It must be noted, however, that even if the associations and networks dedicated to do-it-yourself biology highlight the fact they are open to 'amateurs' and 'citizens', in practice, many of the persons involved already have a strong, often professional, interest in science. We frequently find students or researchers in biology. For example, one of the founders of La Paillasse in Paris is a PhD student in synthetic biology, Madlab in Manchester is collaborating with researchers from Manchester Metropolitan University, and one of the co-founders of D/Ybio is the director of Persona/Genomics.org at Harvard Medical School. Do-it-yourself biology is thus not yet an already established 'amateur science', but rather a 'promised' amateur science, a citizen science 'in the making'.

\section{A community laboratory and a private laboratory}

Let me now describe two laboratories in which do-it-yourself biology takes place: first, a community laboratory and second a private laboratory.

BiologiGaragen was created in 2010 by two young Danes who recently graduated at the Technical University of Denmark: Martin Malthe Borch (who holds a Master's degree in biotechnology) and Marc Juul Christoffersen (who is an IT/biotech engineer). Explaining the rationale behind BiologiGaragen, Borch states: 'It's a way to 'play around' with science, have fun and socialize. Artists are constantly playing, and form creative collectives where they play. Why shouldn't natural science do the same? [...] We are all biologists. DIYbio is about knowledge-sharing, open science, education and lab space for everybody' (cited in Tachibani 2011). On its website, the laboratory insists that it wants to 'encourage citizen science in biology and make knowledge, tools and software available for people to develop solutions based on their personal, local and specific needs'. BiologiGaragen has been set up and is currently located in Labitat, a makerspace in the Frederiksberg district of Copenhagen, Denmark (see picture 2). Membership to both BiologiGaragen and Labitat is free, but a minimum monthly donation of 150 Danish Krones (20 Euros) is required from members for a $24 / 7$ access (and thus not being dependent on other persons to let them in). BiologiGaragen counts today around 50 members on its 
mailing list, out of which 5 are particularly active.

In order to build its laboratory, BiologiGaragen made a call for donations of scientific equipment on its website, 'for all kinds of used wet-lab equipment. Currently especially: freezer, refrigerator [...] $\mathrm{pH}$-sensors, water bath, incubator, autoclave'. Several people responded to the call and sent free equipment. In fact, the call for donations was so successful that today some equipment even has to be refused because of a lack of space.

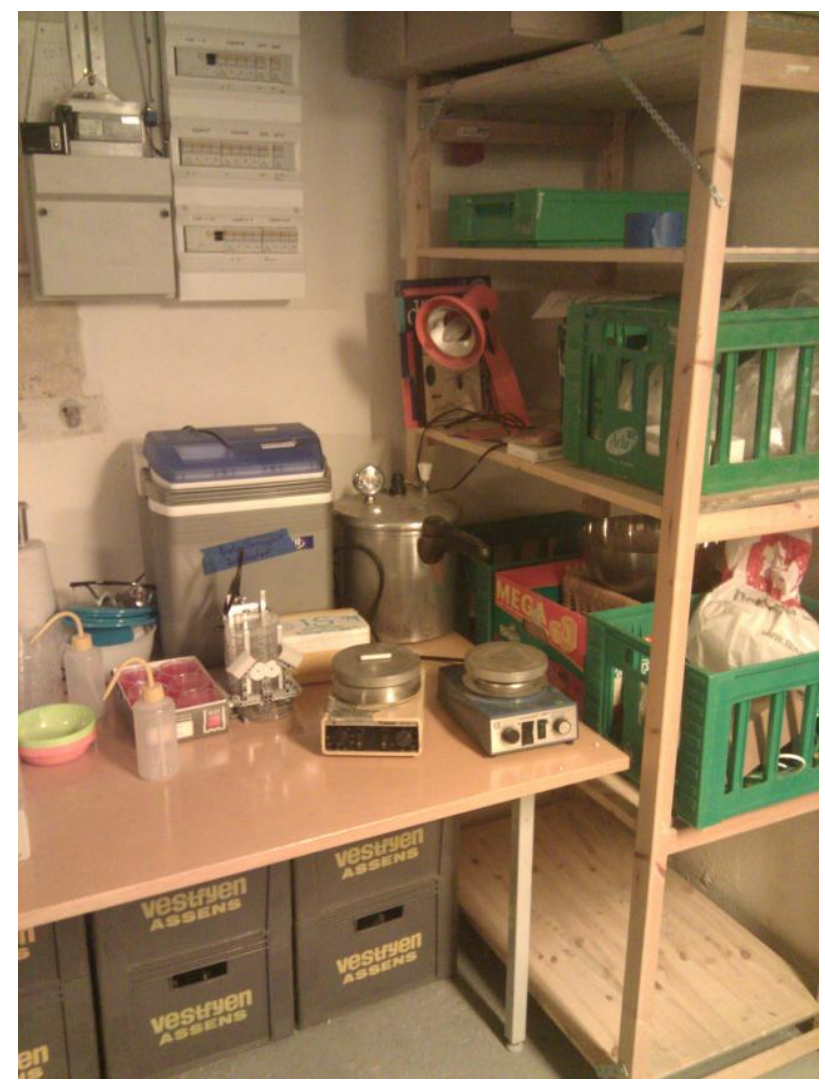

Picture 2: BiologiGaragen in Labitat, Copenhagen.

On the lab bench we see, amongst others, a self-made incubator, 2 stirring plates, and a pressure cooker (used as an autoclave) (source: BiologiGaragen @ Labitat).

A wide range of activities took place over the past 2 years in BiologiGaragen. For instance, there have been activities for hacking laboratory equipment, such as transforming a webcam into a microscope, building one's own centrifuges, stirring plates, incubators and sterile hoods. Other activities have been dedicated to biology itself, for example the hacking of yoghurt, the extraction and visualization of DNA, the idea to build a bioreactor to produce lactic acid or clean the water from a kitchen-sink. The 'Reclaim your Yoghurt' event held in March 2012, for instance, was intended to 'demystify the fermentation process': attendees were given a comprehensible introduction and recipes to do microbiology, they experimented with microorganisms in yoghurt and bread (they also tasted the results), and the knowledge and experience gained can be potentially used in people's 'own kitchens'. On its wiki, Labitat has a whole list of projects, which are subdivided according to their discipline 
(i.e. living biology, software, electronics, mechanics) and according to the motivations behind them (i.e. 'science', 'fun' and 'education'). In addition, there have been events where the practices, ethics and social aspects of do-it-yourself biology have been discussed. Very recently, BiologiGaragen was also involved in an exhibition called BioHacking: Do it yourself! at the Medical Museion in Copenhagen. The exhibition, which runs from January until March 2013 consists of an open laboratory built within the museum and events and workshops to allow visitors to do experiments, meet biohackers and discuss with natural and social scientists "about the dreams and realities of opening up biology in public". As we see, BiologiGaragen is concerned with more than just the 'science' of biology; it is a place concerned with the techniques, the politics, the sociability and the ethics of biology.

A famous story of a private laboratory, which has been reported in many media (Le Monde, Sky News) as well as in academic journals (Alper 2009, Wolinski 2009), is the story of Kay Aull, a student in bioinformatics at the University of California, San Francisco. For the price of around 1000 dollars, Aull set up a small laboratory in her apartment (see picture 3). The devices she built and uses include: a rice cooker to distil water; an incubator made from a polystyrene packaging box, a thermostat from an aquarium, a fan, a heating pad, and a digital thermometer; an electrified box (to separate DNA) built from a picture frame and a plastic box lined with aluminium foil; blue light (to be able to see the DNA) from a blue Christmas light; a thermocycler and an electrophoresis supply bought from eBay (Wohlsen 2011, Moore 2009). Using these rather basic tools she was even able to build a hemochromatosis test (her father was diagnosed with the genetic disease called hemochromatosis and she wanted to find out if she also carried the mutation - which she does).

Commenting Aull's test, journalist Wohlsen (2011: 15) writes: 'Aull's test does not represent new science but a new way of doing science. A practical piece of biotechnology based on the most sophisticated science available was built in a closet using tossed-off gear'. In Technology Review, a popular magazine dedicated to technology, one of Aull's experiments is described in a detailed and richly-illustrated way: we read that she uses ordinary cotton-buds to take samples of cells from her mouth; how she then cuts the cotton-buds and puts them into a tube; how she uses a potato-masher and a pot with boiling water to extract the DNA from her cells; how she amplifies her DNA by using a standard syringe and enzymes bought online, using a recipe also available online (Karberg 2009). As we see, it is worth to tease out the geography and the materiality of this 'new way of doing science', for it takes place at multiple levels: in terms of the accessibility and realize-ability of scientific experiments for non-specialists, in terms of the availability and circulation of experimental protocols, in terms of the cost of equipment, and in terms of the possibility to study one's own body and DNA. Through her experiments, Aull hopes to 'demystify' the process of genetic testing, by showing that 'it's not magic'. 'That's a useful lesson, even though most people will choose a commercial provider instead of attempting DIY. [...] we need to encourage non-specialists to engage with this kind of 
information' (quoted in Wolinski 2009: 685). In other words, we do not only observe a new way of doing science, but also efforts for communicating, domesticating and rendering more accessible the doing of science. Aull's experiment can thus also be conceived as an act of 'demonstration': a practice that is not only concerned with showing science per se, but that is also socio-political for it attributes a social value, shows the feasibility of a process, and tries to convince and enrol actors.

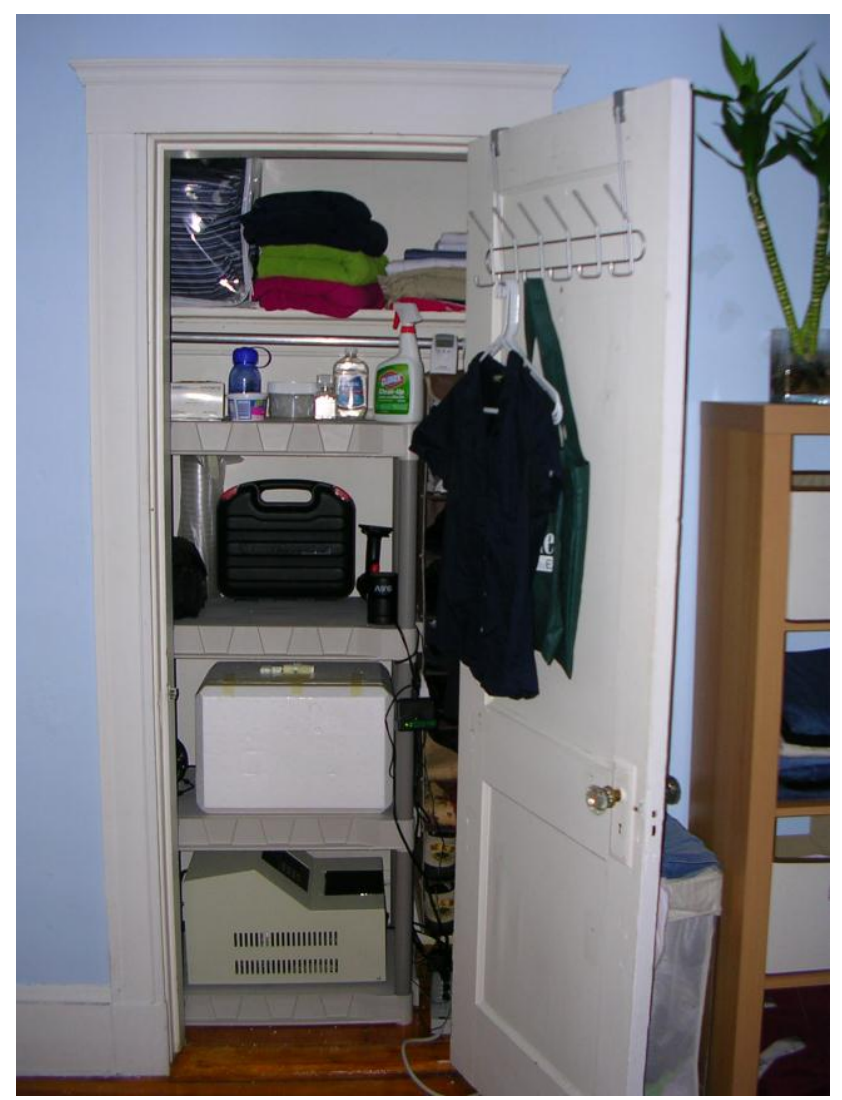

Picture 3: Kay Aull's laboratory in her closet.

On the bottom shelf there is a thermocycler, on the shelf above her self-made incubator (source: Kay Aull).

\section{Scientific equipment and creative workarounds}

As we have already seen above, a key issue for doing do-it-yourself biology is the cost and procurement of scientific equipment. Indeed, until recently it was almost unthinkable that private individuals could build their own biology labs because purchasing scientific equipment was expensive, difficult, uncommon, or just impossible. However, the affordability and availability of scientific equipment has risen a lot over the past few years. There are now various ways through which the costs of setting up a laboratory at home (or a community lab) are becoming more affordable: buying used equipment, transforming equipment, or finding alternatives to equipment. Here are some examples of alternative and transformed equipment that 
frequently feature on websites, videos, or articles devoted to do-it-yourself biology: converting a webcam into a microscope (by removing the lens and putting it back on backwards), the DremelFuge as a substitute for a conventional centrifuge (see picture 4), putting test tubes in one's own armpits to incubate them, using a pressure cooker instead of an autoclave, purifying DNA with a mixture of non-iodized table salt, tenderizer meat and shampoo, using an Open Gel Box instead of a standard one. $^{1}$

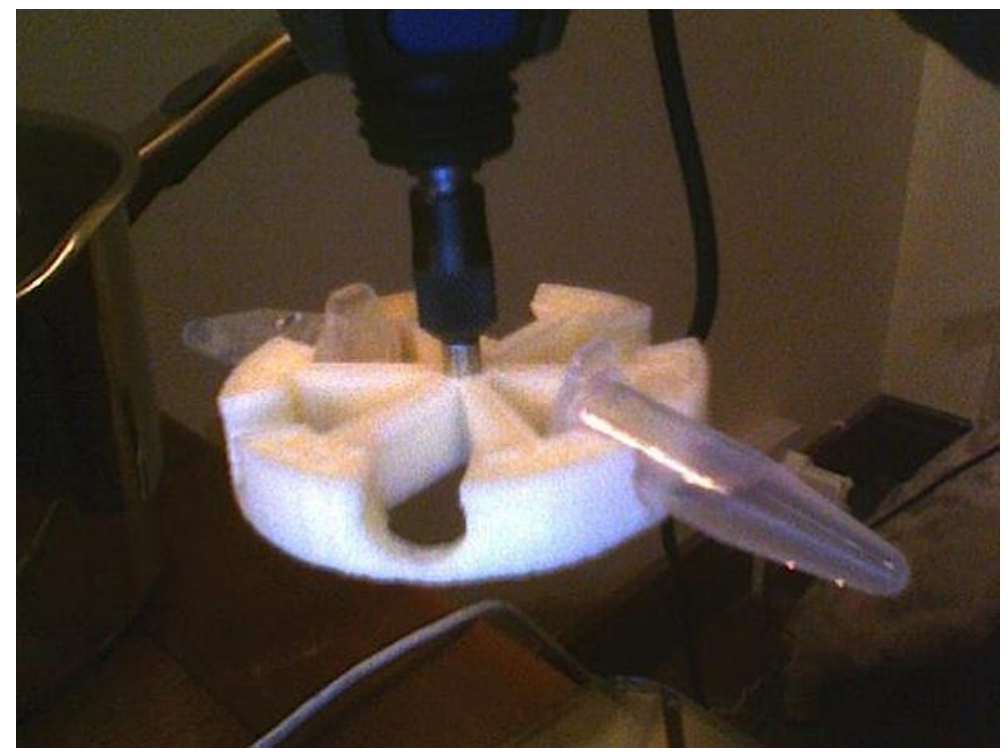

Picture 4: The DremelFuge.

The DremelFuge was created in 2009 by Cathal Garvey and can be used as a substitute to a conventional centrifuge. The idea is to put the device on a power drill or any other rotary tool in order to spin test tubes (source: Cathal Garvey).

Several alternatives to the PCR machine, for instance, have recently been developed. The Open PCR Machine is an open source tool developed in San Francisco by two engineers and is available since 2011. While a conventional PCR machine - essential in biology to amplify DNA and RNA sequences - costs around 3000 dollars, the Open PCR can be ordered online for 600 dollars in the form of a kit containing the different elements. After having ordered the machine, one must then assemble the different parts at home (installation takes between three and five hours). The tools that are required for the assembly are a standard screwdriver and pliers. On the website of Open PCR, instructions for how to build the machine are available in a 74-page document, which explains in a detailed way and with numerous drawings and pictures the process (a bit like the instructions for IKEA products, see picture 5). In the near future it might also be possible to purchase the LavaAmp, an even smaller version of the PCR machine which, according to its designers, has the following benefits: 'High speed. Low cost. High quality. Easily

\footnotetext{
${ }^{1}$ The Open Gel Box project aims to 'create a professional grade open and extensible electrophoresis gel box, available as design documents, unassembled, and assembled kits for researchers to obtain and improve upon'.
} 
portable'. And there is Amplino, a project developed by three Dutch do-it-yourself biologists and presented at the 2012 iGEM competition (iGEM (international Genetically Engineered Machine) is a competition for undergraduate university students in synthetic biology to design biological systems). The idea behind Amplino is to build a PCR system that can be used in developing countries as a tool to detect malaria in under 40 minutes by using a single blood drop.
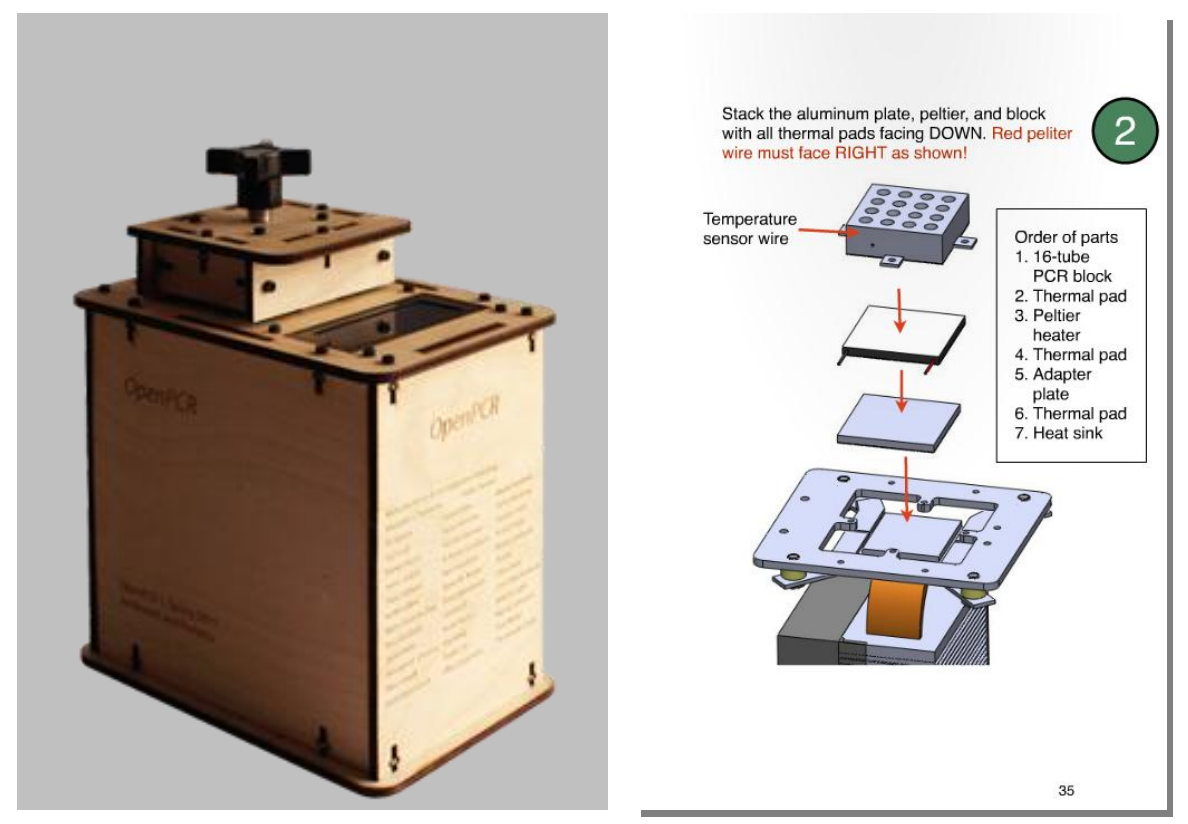

Picture 5: The Open PCR.

On the left, the Open PCR machine; on the right, a page from the build instructions (source: openpcr.org).

Equipment like these help to decrease the costs of setting up a laboratory by the factor of 10 up to 100 . Do-it-yourself biologists can buy these products either via the websites of those who produce them or, in the case of used equipment, via eBay, Amazon, or Craiglist. For these and other kinds of equipment, there are video instructions to build and use them on sites such as YouTube or Vimeo. And, on many blogs, platforms and websites dedicated or related to do-it-yourself biology (i.e. openwetware.org, protocol-online.org, instructables.com, diybio.org), there is information about where and how to purchase, build, or transform equipment. The Internet provides do-it-yourself biology practitioners platforms through which used equipment can be sold and bought, ways for people to share instructions and information for how to find and build alternative tools, and, more generally, a medium to connect people interested in do-it-yourself biology. In fact, the Internet plays an important role in the emerging, alternative, and multifarious economy of scientific equipment that sustains - and is sustained through - do-it-yourself biology. These economies, which we might call 'citizen biotech-economies', are portrayed as open, collective and decentralized and they aim at fostering a material re-distribution, a 
democratisation and an alternative to established science (Meyer 2012). It would certainly be interesting to observe, over the coming years, how these new economies of affordable science objects evolve. Parallels with the open source movement are visible: this economy is based on the movement of goods (to build laboratories), it represents a particular mode of circulation (free circulation/distribution) and authorizes and even encourages changes to the goods being circulated (Cremer and Gaudeul 2004). One of the key rationales behind the networks, websites and wikis dedicated to do-it-yourself biology is to enable and encourage people to 'freely reveal' (von Hippel 2005: 77-91) their innovations.

This does not mean, however, that do-it-yourself biology develops completely outside of market logics. There are already a number of companies more or less closely linked to do-it-yourself biology: Ginkgo Bioworks who sells kits that contain DNA biobricks, Pearl Biotech who sells a gel-box called Pearl Blue Transilluminator (and explicitly acknowledges knowledge gained by developing the Open Gel Box) and LavaAmp, a small PCR machine. A number of do-it-yourself biology laboratories have benefited from laboratories and companies selling, or donating, equipment: the biotech company Codon Devices sold its equipment after having gone bankrupt (Roosth 2010: 120), the Parisian community laboratory La Paillasse received donations from a research institution and a former laboratory from the municipality of Paris, and BiologiGaragen received donations from the company Novozymes. There is thus a multifarious relationship - and potential tension - between do-it-yourself biology and the corporate end of science: a relationship of dependency concerning cheap, second-hand or specialized products for amateurs; the potential and entrepreneurial drive to transform 'hacked' equipment into commercial equipment; an ethics of openness and sharing that potentially stands at odds with patents, licenses and business ventures; a politics against the monopolization of access versus a politics seeking to secure and maintain privileged/economic access.

Three points can be made here. First, do-it-yourself biology is not only dependent on scientific equipment becoming cheaper and more available. The mutability of objects is also crucially important. Mundane objects and modest resources can be transformed into scientific tools. Second, while a causal relationship between cheap tools and the rise of do-it-yourself biology is often put forward, the opposite argument holds true as well: practicing do-it-yourself biology calls for creative solutions to deal with the fact that scientific equipment is usually expensive and hard to come by. In other words, do-it-yourself biology favours so-called 'creative workarounds' that is, inventive ways to work without conventional and expensive material (I borrow the term 'creative workarounds' from Ledford (2010) who does not, however, provide a definition of the term in her article). Do-it-yourself biology fosters at least two sorts of creative workarounds. On the one hand, people use creative workarounds around objects when they transform and combine them and use them in unusual ways. On the other hand, we have also seen creative workarounds around institutions, when people try to circumvent established industry-university business linkages (i.e. via 
donations or imitations of equipment). Put another way, these creative workarounds provide two sorts of détournement: objects are diverted from their primary use, and to the usual routes on which scientific equipment travels, alternative routes are added.

A third point worth stressing here is that objects play a key role in blurring or maintaining the boundaries of science. A lot of the tools do-it-yourself biologists use are rather cheap, ubiquitous, and easy to use, which makes them, in other words, relatively mobile. The fact that a lot of these objects, such as the Open PCR, are accessible as open source tools further increases their mobility. This transportability of scientific tools and material helps to explain why some scientific fields are more open to amateurs than others (Meyer 2008). Thus, when outlining the spaces of amateur science we have to include - beside disciplinary spaces and physical places - the networks and trajectories of material objects in our analyses.

\section{Boundary-work}

Do-it-yourself biology is often imagined and discussed in terms of boundaries that are crossed: between the university and the home, between amateurs and experts, scientists and citizens, public and private spaces, controlled spaces and spaces difficult to control, institutions and non-institutions. The founder of the community lab BioCurious even argued that people who tinker with biology at home 'are creating a dream of biotech without borders' (Gentry 2011). At the same time, however, many boundaries are (re)emphasized and policed: between responsible and criminal usages of technology, between open science and corporate science, between the safe handling of the biological and hazardous experiments, between hacking and breaking the law, between the laboratory and - especially if dangerous organisms are experimented with - the exterior world. Also, in some of their comments, scientists emphasize a difference of kind between do-it-yourself biology and university-based biology. For example, in an article published in Nature we read:

Most biohackers are hobbyists who delight in crafting their own equipment and who tackle projects no more sophisticated than those found in an advanced high-school biology lab [...] it is not necessarily the sophistication of the techniques, but the questions to which they are applied, that makes for compelling science (Anonymous 2009a).

Other commentators put forward disparities in terms of costs:

[...] the high financial and educational barriers to cutting-edge molecular biology means that garage labs are unlikely to solve the world's energy or health problems any time soon (Anonymous 2009a). 
you do need hefty initial investments to make novel discoveries. That's not to say that DIY biohackers can't make contributions to science. But I do have a hard time seeing the cutting edge, fundamental research reaching the hobbyist laboratory, simply because of its associated expense and uncertainty (Sawyer 2011).

The boundary can, however, also be problematic for it makes it difficult to regulate science done at home:

biosafety guidelines [...] are aimed at institutional biosafety officers with training in the field. Laden with jargon and focused on advanced work with dangerous chemicals and pathogens that hobbyists are unlikely to encounter, the guidelines are little help in the garage (Anonymous 2009a).

Here, the boundary drawn is one of language and terminology. Some objects, like technical guidelines, seem to be unable to travel between professional and amateur spaces, since they require a too great technical knowledge. Interestingly, safety concerns were also put forward as one of the reasons why DIYbio was banned from taking part in the iGEM competition in 2009 (see Alper 2009). Here is the rationale:

Because there is no formal safety framework or guidelines or precedent for amateur teams working outside of traditional labs, iGEM is afraid of the potential safety liability and doesn't want amateur teams to participate until there is some kind of framework (DIY website).

This is arguably the clearest evidence of exclusion of amateurs from institutionalized biology. In recent years, however, the links between do-it-yourself biology and the iGEM competition have been increasing, either through direct collaborations or via projects that aim at providing accessible tools and techniques for do-it-yourself practitioners.

In discussion about do-it-yourself biology, numerous boundaries are currently explicitated, discussed, and negotiated and a variety of boundary dynamics are visible. First, we see the creation of a name, of a domain: 'garage biology', 'do-ityourself biology', 'DIY biology', etc. This rather mundane practice of giving a name creates boundaries - boundaries that are constitutive and, we might argue, help to structure and publicize emerging practices. Second, we have seen that boundaries can become permeable. This does not mean that the boundaries around biology vanish altogether, but that there are exchanges and that there is communication across the lines that separate private homes, community laboratories and scientific institutions. In other words, the boundaries of molecular biology are 'semi-permeable' (Mol and Law 2005). Third, we can also observe the maintaining of boundaries, above all in order to protect science's authority, autonomy and distinctiveness. Scientists do emphasize various kinds of boundaries to demarcate and distinguish 
their practices from other practices - they do so by invoking costs, safety, the kinds of questions asked, etc. At the most extreme, there is evidence of expulsion of amateur science from professional science (i.e. DIYbio being banned from taking part in iGEM).

Fourth, one consequence of the fact that do-it-yourself biology takes place outside institutions - and a response to some of the critiques and fears voiced - is the establishment of ethical and safety standards. Two conferences dedicated to do-ityourself biology took place in 2011 (one in London, the other one in San Francisco) at which a 'code of ethics' was presented and discussed. The draft code of ethics from the European conference states (see picture 6), for example, that do-it-yourself practitioners should 'emphasize transparency', 'adopt safe practices', and 'respect humans and all living systems'. While this ethical and safety framework is being established in a bottom-up, collective and self-governed way, it remains to be seen how such a global set of ethical principles will be adapted or prescribed in local contexts. It will thus be interesting to follow the ethicization of do-it-yourself biology and how these codes will circulate and be adopted, and to what extent they will be able, or not, to establish binding rules for do-it-yourself practices.

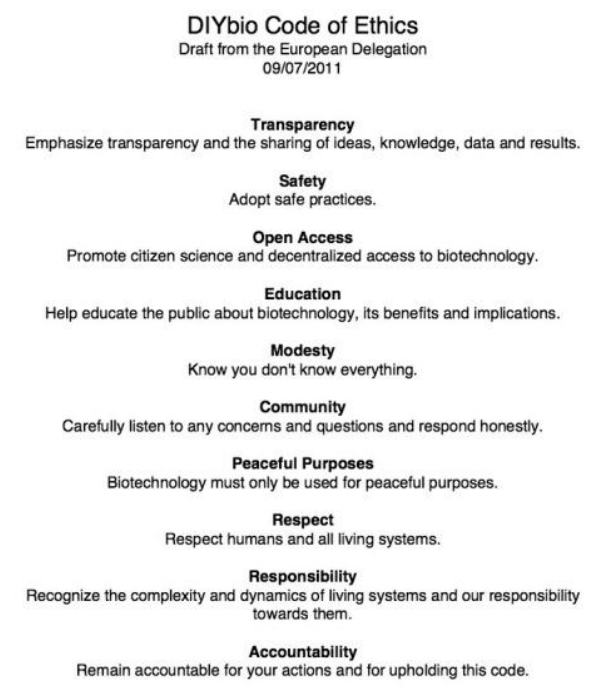

Picture 6: The DIYbio Code of Ethics (from the European Delegation) (source: diybio.org).

In discussions and debates about do-it-yourself biology a multitude of boundary dynamics are apparent. Some boundaries are constructed, some maintained, other boundaries can become permeable, almost disappear, or rather displaced. The events and discussions at which this policing, making and unmaking of boundaries 
takes place is interesting for several reasons: they show that boundary-work is a process that takes various forms (cultural, social, material); they are a privileged site for observing how science is qualified, legitimized, valued, compared, demarcated or disqualified; and they allow us to examine the materiality of boundaries for, as we have seen, demarcations and/or hybridizations are related to the locations, tools and objects in/with which science is practiced. In other words, what we see is that boundary-work is not only a cultural and discursive practice but also a material and spatial one (see also Michael 2002: 370).

\section{Conclusion}

To conclude, I want to suggest that three features make do-it-yourself biology a particularly interesting topic: its geographies and material culture, the use of objects and 'creative workarounds', and how it brings together the individual (the 'yourself') and the collective. Rather than focusing on the cultures of do-it-yourself biology, my concern in this article was to concentrate on the material culture of the field: its locations, its equipment, its materialities, its spaces, its objects. The emergence of do-it-yourself biology is mainly located in the Western world, especially in major US and European cities. Do-it-yourself biology takes place, above all, in industrialised and urban spaces, usually not far from the academic world. Beyond these territorial aspects, the more distributed geographies of protocols, ideas and objects that circulate via Internet forums and collaborative platforms play a key role in the emergence of do-it-yourself biology. In fact, the various communicative devices that do-it-yourself biologists use - i.e. the diybio.org website, the blogs, open source tools, forums, videos, etc. - are part and parcel of the material infrastructure that allows for the circulation of knowledge to take place, for collectives of do-it-yourself biologists to emerge, and for various kinds of boundaries to be overcome.

The second point I want to stress is that in order to explore the 'domestication' of molecular and synthetic biology, it is not only worth describing and tracing the objects that travel in-between various places and people. It is also interesting to examine what happens to these objects, how they are transformed, combined, and (re)made. We have seen various practices throughout this article: objects being transformed into other objects, made from scratch, replaced by objects, replicated, imitated, etc. Do-it-yourself biology is a site of creative 'workarounds' around objects and around institutions. These workarounds open up new spaces for amateur science: they enable people to build community laboratories as well as laboratories in their own garages, kitchens, or basements. The relationships between amateurs and professionals are thus not only located 'in' disciplinary fields or specific places (the usual sites to locate the amateur/professional boundary), they are also made possible 'through' objects. I would argue that the affordances of objects - as much as their mobility and their malleability - thus need to be taken into account in analyses of 
do-it-yourself biology.

A third theme that emerged throughout the paper is the relationship between the individual (the 'yourself') and do-it-yourself biology as a collective. In order to set up a laboratory in a garage or basement, people depend on other people interested in doit-yourself biology, on scientific institutions, on the sharing of information, on the circulation of objects, on Internet platforms, on emails, on donations, etc. In other words, the 'yourself' has to be connected: the form of individualism that we observe is a sort of 'connected individualism' (Flichy, 2004), halfway between individual practices and group practices, between the logics of autonomy and the logics of networks. While people might themselves build their own laboratory at home, and while they might even do so in opposition to institutionalized science, they need to tap into the emerging collectives of people, ideas and objects that this article has described. Because of this need for connectivity and collectivity, the term 'yourself' might appear as a misnomer. Yet, 'yourself' symbolizes more than just a passive, individual person. 'Yourself' stands for someone that engages with biology and literally does things, a self that is active and that is juxtaposed to other sites and scales of science production: the university, the institution, the enterprise, etc. Do-ityourself biology thus aims to constitute a distinct and political form of self by providing people access, by enabling them to transform themselves into active producers of science, by making their bodies and aliments more knowable, and by demonstrating that one can do it oneself. ${ }^{2}$ The extent to which this individualization and redistribution of biology increases the democratization and the 'tinkerability' (Anonymous 2009c) of biology thus merits further analysis. The moral and political consequences of these shifts also deserve our attention, since domesticating biology and experimenting with life outside institutional frames opens up new questions and debates about the boundaries, the sociabilities and the ethics of biology.

\section{Acknowledgements}

Thanks to Francesca Musiani, Liliana Doganova, Susan Molyneux-Hodgson, Martin Malthe Borch (BiologiGaragen), Florian Charvolin, Alessandro Delfanti, Johan Söderberg, Jean Foyer, Thomas Landrain (La Paillasse) and Sara Tocchetti for comments and discussions.

\footnotetext{
${ }^{2}$ The parallels with the do-it-yourself ethics of the punk movement - i.e. recording and performing music in underground venues, modifying clothes rather than buying new ones, stressing that anyone can make music, fostering practices of collage and cut-and-paste, being anti-consumerist/capitalist can be highlighted here.
} 


\section{References}

Alberti, Samuel (2001) 'Amateurs and Professionals in One County: Biology and Natural History in Late Victorian Yorkshire', Journal of the History of Biology 34(1): 115-147.

Alper, Joe (2009) 'Biotech in the basement', Nature Biotechnology 27: 1077-1078.

Anonymous (2009a) 'Garage Biology. Amateur scientists who experiment at home should be welcomed by the professionals', Nature 467(7316): 634.

Anonymous (2009b) 'Taking Biological Research Out Of The Laboratory', National Public Radio, 27 December 2009, available online at: http://www.npr.org/templates/story/story.php?storyld=121954328.

Anonymous (2009c) 'Increasing tinkerability - explaining DIYbio', The Molecularist, available online at: http://www.molecularist.com/2009/12/increasing-tinkerability-explainingdiybio.html.

Bennett, Gaymon, Gilman, Nils, Stavrianakis, Anthony and Rabinow, Paul (2009) 'From synthetic biology to biohacking: are we prepared?', Nature Biotechnology 27:1109-1111.

Brown, Phil (1992) 'Popular Epidemiology and Toxic Waste Contamination: Lay and Professional Ways of Knowing', Journal of Health and Social Behavior 33(3): 267-281.

Callon, Michel (1998) 'Les différentes formes de démocratie technique', Annales des Mines, Janvier, 63-73.

Callon, Michel, Lascoumes, Philippe and Barthe, Yannick (2001) Agir dans un monde incertain. Essai sur la démocratie technique, Paris: Seuil.

Carlson, Rob (2001) 'Open-Source Biology And Its Impact on Industry', IEEE Spectrum 5: 15-17.

Carlson, Rob (2005) 'Splice It Yourself. Who needs a geneticist? Build your own DNA lab', Wired Magazine, No. 13.

Charvolin, Florian, Micoud, André and Nyhart, Lynn (eds) (2007) Des sciences citoyennes ? La question de l'amateur dans les sciences naturalistes, Éditions de l'Aube: La Tour d'Aigues.

Cremer, Jacques and Gaudeul, Alexandre (2004) 'Quelques éléments d'économie du logiciel libre', Réseaux 124: 111-139.

Delfanti, Alessandro (2010) Genome Hackers, rebel biology, open source and science ethic, PhD thesis, Milan: University of Milan.

Ellis, Rebecca and Waterton, Claire (2005) 'Caught between the cartographic and the ethnographic imagination: the whereabouts of amateurs, professionals, and nature in knowing biodiversity', Environment and Planning D: Society and Space 23(5): 673-693.

Epstein, Steven (1995) 'The Construction of Lay Expertise: AIDS Activism and the Forging of Credibility in the Reform of Clinical Trials', Science, Technology and Human Values 20(4): 408-437.

Evans, Rob (2005) 'Introduction. Demarcation Socialized: Constructing Boundaries and Recognizing Difference', Science, Technology and Human Values 30(1): 3-16.

Finnegan, Diarmid (2008) 'The Spatial Turn: Geographical Approaches in the History of Science', Journal of the History of Biology 41(2): 369-388.

Flichy, Patrice (2004) 'L'individualisme connecté entre la technique numérique et la société', Réseaux 124: 17-51. 
Gentry, Eri (2011) 'Garage Biology and DIYbio: Because We Can, Because We Have to', paper presented at Oscon - Open Source Convention, 28 July 2011, Portland, Oregon.

Gieryn, Thomas (1983) 'Boundary-work and the Demarcation of Science from Non-science; Strains and Interests in Professional Ideologies of Scientists', American Sociological Review 48(6): 781-795.

Gieryn, Thomas (1999) Cultural Boundaries of Science: Credibility on the Line, Chicago: University of Chicago Press.

Guston, Dave H. (2001) 'Boundary Organizations in Environmental Policy and Science: An Introduction', Science, Technology and Human Values 26(4): 399-408.

Heaton, Lorna, Millerand, Florence, Crespel, Élodie and Proulx, Serge (2011) 'La réactualisation de la contribution des amateurs à la botanique. Le collectif en ligne Tela Botanica', Terrains \& travaux 18: 155-173.

Hope, Janet (2008) Biobazaar. The open source revolution and biotechnology, Cambridge: Harvard University Press.

Karberg, Sascha (2009) 'Genbastler Allein zu Haus', Technology Review 11: 28-32.

Kelty, Christopher (2010) 'Outlaw, hackers, victorian amateurs: diagnosing public participation in the life sciences today', Journal of Science Communication 9(1).

Kera, Denisa (2012) 'Hackerspaces and DIYbio in Asia: connecting science and community with open data, kits and protocols', Journal of Peer Production, Issue 2.

Kraft, Alison, and Alberti, Sam (2003) 'Equal though different: Laboratories, museums and the institutional development of biology in Late-Victorian Northern England', Studies in the History and Philosophy of Biological and Biomedical Sciences 34(2): 203-236.

Kuklick, Henrika and Kohler, Robert (eds) (1996) Science in the field. Chicago: The University of Chicago Press.

Ledford, Heidi (2010) 'Life hackers', Nature 467: 650-652.

Livingstone, David (2003) Putting Science in its Place. Geographies of Scientific Knowledge, Chicago: The University of Chicago Press.

Meyer, Morgan (2008) 'On the boundaries and partial connections between amateurs and professionals', Museum and Society 6(1): 38-53.

Meyer, Morgan (2010) 'Caring for Weak Ties - the Natural History Museum as a Place of Encounter Between Amateur and Professional Science', Sociological Research Online 15(2).

Meyer, Morgan (2012) 'Build your own lab: Do-it-yourself biology and the rise of citizen biotech-economies', Journal of Peer Production, Issue 2.

Michael, Mike (2002) 'Comprehension, Apprehension, Prehension: Heterogeneity and the Public Understanding of Science', Science, Technology and Human Values 27(3): 357378.

Mol, Annemarie and Law, John (2005) 'Boundary Variations: an Introduction', Environment and Planning D: Society and Space 23(5): 637-642.

Moore, Thomas (2009) 'DIY DNA: 'Biohackers' Creating Own Bugs', Sky News, 1 August 2009.

Naylor, Steven (2005) 'Introduction: historical geographies of science - places, contexts, cartographies', The British Journal for the History of Science 38(1): 1-12.

Pickstone, John (2000) Ways of Knowing. A New History of Science, Technology and Medicine, Manchester: Manchester University Press.

Powell, Richard (2007) 'Geographies of science: histories, localities, practices, futures', Progress in Human Geography 31(3): 309-329.

Rabeharisoa, Vololona and Callon, Michel (1999) Le pouvoir des malades. L'Association 
française contre les myopathies et la Recherche, Paris: Presses de l'École des Mines.

Rabeharisoa, Vololona, Bonnet, Doris, Callon, Michel and Pouvoirville, Gerard (1998) 'Les associations de malades: entre le marché, la science et la médecine. Avant-propos', Sciences Sociales et Santé 16(3): 5-15.

Roosth, Sophia (2010) Crafting life: a sensory ethnography of fabricated biologies, $\mathrm{PhD}$ thesis, Massachusetts Institute of Technology.

Sawyer, Eric (2011) 'The Promises, Demands, and Risks of Garage Biology', Nature, 18 August 2011, available online at: http://www.nature.com/scitable/blog/bio2.0/the_promises_demands_and_risks.

Secord, Anne (1996) 'Artisan Botany', in N. Jardine, J. A. Secord, and E. Spary, (eds) Cultures of Natural History, pp. 378-393, Cambridge: Cambridge University Press.

Shapin, Steven (1988) 'The house of experiment in seventeenth-century England', Isis 79(3): 373-404.

Shove, Elizabeth, Watson, Matthew, Hand, Martin and Ingram, Jack (2007) The Design of Everyday Life, London: Berg.

Star, Susan Leigh, and Griesemer, James (1989) 'Institutional ecology, "translations" and boundary objects: Amateurs and professionals in Berkeley's museum of vertebrate zoology, 1907-39', Social Studies of Science 19(3): 387-420.

Tachibani, Chris (2011) 'We are all biologists', Life Sciences Insight 1: 42-45.

Von Hippel, Eric (2005) Democratizing Innovation, Cambridge: MIT Press.

Wohlsen, Marcus (2011) Biopunk: DIY Scientists Hack the Software of Life, New York: Current.

Wolinsky, Howard (2009) 'Kitchen biology', EMBO Reports 10(7): 683-685. 